\title{
PERANAN KYAI HAJI IBRAHIM DALAM DAKWAH DAN PENDIDIKAN
}

\author{
Zainap Hartati*
}

\begin{abstract}
Kedatangan Islam di Kalimantan Tengah tak terlepas dari peran para ulama maupun da'i yang berasal dari Kalimantan Selatan, melalui jalur perdagangan, perkawinana dengan jalan damai, terutama melalui jalur sungai. Salab satu ulama/da'i yang berperan terhadap perkembangan, penyebaran dan penyampaian Islam adalah KH. Ibrahim bin Muhammad Nuh, namun sayang sosok ulama ini secara tulisan maupun penelitian belum terungkap, sehingga keberadaannya, terutama peranannya dalam dakwah dan pendidikan perlu diungkapkan, sebagai contoh, untuk dapat diteladani secara luas keberadaan peranan tersebut. Peranan dakwah KH. Ibrahim terungkap pada aktivitas dakwah dan pendidikannya, sikeap yang ditampilkan dan referensi yang ada bingga saat ini, berupa buku Taubid berjudul "Hidayatul Insan Fita'limiddin Taubid", merupakan materi tentang pelajaran sifat dua puluh tulisan tangan beliau dengam huruf Arab Melayu.
\end{abstract}

Kata kunci: Pendidikan, Dakwah, Teladan.

\section{Pendahuluan}

Agama Islam adalah agama yang disebarkan dengan penuh kedamaian: rahmatan lil 'alamin, berkembang di Indonesia diperkirakan sekitar abad ke-11 dan ke-12 M. Penyebaran pertama kali diterima oleh masyarakat Indonesia di sekitar pesisir pantai yang dilakukan oleh para pedagang Arab sambil menjajakan barang dagangannya.

Perkembangan agama Islam selanjutnya selain melalui jalur perdagangan juga melalui perkawinan. Peran para ulama, tokoh agama dan para Da’i yang berjuang karena Allah semata dari wilayah satu ke wilayah yang lainnya.

Penyebaran ajaran Islam dilakukan kepada semua kalangan masyarakat tanpa memandang harkat dan martabat, karena Islam tidak membedakan satu

${ }^{*}$ Dosen STAIN Palangka Raya Jurusan Tarbiyah, alamat : Jl. Yos Sudarso No. 104 Palangka Raya. email : zainap.hartati@yahoo.com, hp. 081345521235. 
dengan yang lainnya, yang membedakan hanyalah ketaqwaannya, sebagaimana firman Allah swt ${ }^{1}$ yang berbunyi :

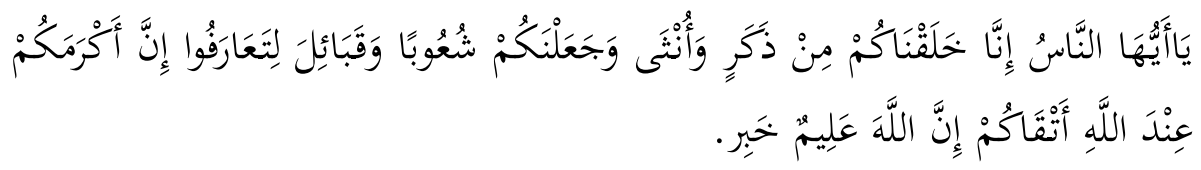

"Hai manusia, sesunggubnya Kami menciptakan kamu dari seorang laki-laki dan seorang perempuan dan menjadikan kamu berbangsa-bangsa dan bersuku-suku supaya kamu saling kenal-mengenal. Sesunggubnya orang yang paling mulia diantara kamu disisi Allah ialah orang yang paling bertaqwa diantara kamu. Sesungguhnya Allah Maha Mengetabui lagi Maha Mengenal".

Sebagai agama yang penuh dengan kedamaian, dengan mudah dapat diterima di kalangan penerima ajaran agama Islam, sehingga terjalin hubungan yang baik, baik karena kepentingan ekonomi maupun politik, solidaritas agama telah memudahkan hubungan antara pendatang dan penerima tamu (masyarakat setempat). Islam semakin kuat dan berani di kalangan masyarakat para penerima berusaha belajar dan memahami ajaran agama Islam tersebut, selanjutnya mewariskan kepada kalangan keluarga dan masyarakat sekitar, lamakelamaan Islam menjadi panutan masyarakat banyak.

Sebagai agama yang penuh semangat damai, hingga menjadi umat mayoritas, demikian juga halnya di Kalimantan Tengah. Penyebaran agama Islam dilakukan oleh para pedagang dan Da’i dari Provinsi Kalimantan Selatan, seperti Da'i keturunan Syekh Muhammad Arsyad al-Banjari. Syekh Muhammad Arsyad al-Banjari adalah seorang ulama dari Kalimantan Selatan yang dilahirkan di sebuah desa dekat Martapura sekitar tahun $1780 \mathrm{M}^{2}$

Kedatangan Islam di Kalimantan Tengah sebagaimana yang pernah diteliti, baik di wilayah Kotawaringin Barat, Kotawaringin Timur, Barito dan Kapuas, tak lepas dari peran dari para Da'i dan ulama dari wilayah Kalimantan Selatan bahkan para Da’i keturunan Syekh Muhammad Arsyad al-Banjari

${ }^{1}$ Q.S. al-Hujurat ayat 13.

${ }^{2}$ Asywadie Syukur, Pemikiran Syekh Muhammad Arsyad al-Banjari, dalam bidang Taubid dan Tasawuf, (Banjarmasin: Comdes. 2009), h.v. 
tersebut, melalui jalur perdagangan maupun perkawinan, dan kedatangan Islam tersebut dengan jalan damai melalui jalur sungai. ${ }^{3}$

Saat ini, Islam telah dianut oleh berbagai lapisan masyarakat, hal ini memberi peluang untuk memperkuat pemahaman/ajaran Islam tersebut, walaupun terkadang pelaksanaannya masih bercampur dengan tradisi penduduk asli. Pemahaman dan pengamalan Islam sebagai agama yang damai perlu terus dilakukan pembinaan dan pengajaran yang lebih mendalam, hal ini dituntut keberadaan para Da'i, ulama ataupun tokoh agama untuk memberikan siraman rohani keislaman, sehingga tetap pada ajaran Islam yang telah dibawa dan diajarkan Nabi Muhammad saw.

Bukti nyata peran dan keberadaan seseorang untuk mengajak kepada ajaran Islam yang murni, adanya ulama dengan sebutan 'kyai' maupun 'tuan guru' sebagaimana di Kota Palangka Raya, eksistensi keagamaan seperti adanya madrasah, pondok pesantren, majelis-majelis taklim dan sebagainya. Salah satu kyai yang turutserta menyebarkan dan menyampaikan ajaran Islam kepada masyarakat secara luas, baik dalam bentuk majelis taklim maupun menemui masyarakat secara langsung adalah Kyai Haji Ibrahim (KH. Ibrahim).

KH. Ibrahim (almarhum) hingga saat ini peran dalam dakwah dan kependidikan secara Islam masih ada seperti: Pondok Pesantren Hidayatul Insan Fita'limiddin, Majelis Taklim Hasbunallah maupun madrasah dalam naungannya.

Namun demikian, sangat disayangkan sosok KH. Ibrahim tersebut hingga saat ini belum penulis temukan baik dalam bentuk tulisan maupun penelitian, sehingga keberadaan perannya dapat diteladani dan dicontoh bagi masyarakat luas, walaupun dari pembicaraan orang perorang, kelompok perkelompok majelis taklim pada masa beliau masih hidup telah cukup diketahui, sehingga peneliti tertarik untuk melakukan penelusuran secara historis tentang peran $\mathrm{KH}$. Ibrahim dalam dakwah dan pendidikan Islam di Kota Palangka Raya.

Rumusan masalah yang diangkat : 1) Bagaimana biografi KH. Ibrahim, dan 2) Bagaimana peranan KH. Ibrahim dalam dakwah dan pendidikan. Sedangkan tujuan penelitian ini adalah : 1) Mendeskripsikan biografi tentang KH. Ibrahim, 2) Mendeskrip dan menganalisis peranan KH. Ibrahim dalam dakwah dan pendidikan. Sehingga penelitian ini diharapkan dapat bermanfaat

${ }^{3}$ Khairil Anwar, dkk, Kedatangan Islam di Bumi Tambun Bungai, Banjarmasin: STAIN Palangka Raya bekerjasama dengan MUI Kalteng, 2005, h. 103-105. 
untuk : 1) Sebagai dokumentasi keberadaan ulama KH. Ibrahim, 2) Sebagai upaya sosialisasi peran ulama dalam dakwah dan pendidikan Islam, dan 3) Referensi bagi penelitian selanjutnya.

Penelitian ini menggunakan metode sejarah dengan pendekatan deskriptif kualitatif, dengan teknik penggumpulan data: Wawancara, dokumentasi dan observasi, kemudian data diolah dengan tahapan: Reduksi data, klasifikasi data, display data dan interpretasi dan pengambilan kesimpulan.

\section{Kajian Teoritik}

\section{Penelitian Terdahulu}

Penelitian yang berhubungan dengan peran ulama maupun tokoh agama penyebar ajaran agama Islam seperti :

Fadli Rahman dalam buku yang berjudul "Ma'rifah, Musyahadah, Mukasyafah dan Mababbah", paradigma baru neo sufisme di Kalimantan Tengah, yang membahas tentang biografi dan ajaran tasawuf KH. Haderanie H.N., mengulas pemikiran ulama tersebut dalam hal tasawuf, beliau adalah salah satu ulama kharismatik yang ada di Kalimantan Tengah ${ }^{4}$. Khairil Anwar, dalam buku yang berjudul "Kedatangan Islam di Bumi Tambun Bungai", membahas tentang kedatangan Islam di Kalimantan Tengah meliputi Kotawaringin dan Sukamara. Kotawaringin Timur, wilayah Barito dan Kapuas, dikemukakan juga penyebaran para Da'i, ulama maupun tokoh agama berasal dari Banjarmasin, Martapura, Marabahan, Nagara dan juga keturunan Syekh Muhammad Arsyad al-Banjari. $^{5}$

Penelitian tersebut belum membahas pada keberadaan dan peran KH. Ibrahim, namun demikian ada beberapa penelitian tentang Pondok Pesantren Hidayatul Insan Fita'limiddin sebagai salah satu peninggalan dari KH. Ibrahim, yaitu: Ahmad Kasimi, penelitian tentang pengaruh aktivitas pengajian tasawuf terhadap tingkah laku mahasiswa STAIN Palangka Raya Jurusan Tarbiyah (studi pada Pondok Pesantren Hidayatul Insan Fita'limiddin Palangka Raya), penelitian ini bertujuan untuk melihat berbagai aktivitas mahasiswa mengikuti pengajian tasawuf serta pengaruhnya kepada tingkah laku

${ }^{4}$ Fadli Rahman, Ma'rifah, Musyahadah, Mukasyafah dan Mababbah, Paradigma Baru Neo Sufisme di Kalimantan Tengah, (Malang: In-Trans, 2007).

${ }^{5}$ Khairil Anwar, Kedatangan Islam ..., 2006. 
mahasiswa tersebut. ${ }^{6}$ Jorjani, penelitian tentang komponen dakwah Islamiyah majelis taklim Pondok Pesantren Hidayatul Insan Fita'limiddin di Kecamatan Pahandut Kota Palangka Raya, tujuan penelitian ini untuk mengetahui apa dan bagaimana komponen dakwah Islamiyah tersebut serta kendala yang dihadapi pada dakwah Islamiyah di majelis taklim tersebut. ${ }^{7}$

Penelitian yang akan dibahas ini, berupaya mendiskripsikan biografi $\mathrm{KH}$. Ibrahim dan perannya dalam dakwah dan pendidikan, karena dari beberapa peninggalan beliau seperti Pondok Pesantren dan Majelis Taklim memberikan kontribusi yang baik sampai saat ini, sangat disayangkan kalau ketokohan perintisnya tidak dimunculkan, untuk jadi pembelajaran dan teladan yang baik bagi umat Islam, dan penghargaan kepada hasil karya seseorang, apalagi sebagai pigur seorang ulama/Da'i yang berperan memberikan tenaga dan pikiran untuk umat Islam di Kalimantan Tengah, khususnya di Kota Palangka Raya (dulu adalah Kotamadya Palangka Raya).

\section{Kajian Teoritik}

\section{a. Hakikat Dakwah Islamiyah}

\section{1). Pengertian Dakwah Islamiyah}

Dakwah secara etimologi $i^{8}$ berasal dari bahasa Arab berarti : seruan, ajakan, panggilan, sedangkan orang yang melakukan seruan atau ajakan dikenal dengan panggilan Da'i. Dakwah menurut Muhiddin adalah ajaran agama yang ditujukan sebagai rahmat untuk semua, yang membawa nilai-nilai positif, seperti rasa aman, tentram, sejuk (al-amn), ${ }^{9}$ sebagaimana Q.S. al-An'am, ayat 82.

Menurut istilah, dakwah ${ }^{10}$ adalah seruan Islam, mengajak dan memanggil umat manusia agar beriman dan mempercayai keyakinan dan pandangan hidup Islam. Hasyim dakwah mengajak orang lain untuk meyakini dan mengamalkan

${ }^{6}$ Ahmad Kasimi, Skripsi Pengaruh Aktivitas Pengajian Tasawuf terbadap Tingkah Laku Mahasiswa STAIN Palangka Raya Jurusan Tarbiyah (studi pada Pondok Pesantren Hidayatul Insan Fita'limiddin Palangka Raya), (Palangka Raya: STAIN Palangka Raya, 1998).

7Jorjani, Skripsi komponen Dakwah Islamiyah Majelis Taklim Pondok Pesantren Hidayatul Insan Fita'limiddin di Kecamatan Pahandut Kota Palangka Raya, (Palangka Raya: STAIN Palangka Raya, 2005).

${ }^{8}$ Djalinus Syah (et.al), Kamus Pelajar Kata Serapan Bahasa Indonesia, Jakarta: Rineka Cipta, 1993), h. 31.

${ }^{9}$ Asep Muhiddin, Dakwah dalam Perspektif al-Qur'an, (Bandung: CV. Pustaka Setia, 2002), h. 23 .

${ }^{10}$ Asep Muhiddin, Dakwah ..., h. 17. 
akidah Islam yang terlebih dahulu diyakini dan diamalkan oleh pendakwah itu sendiri. ${ }^{11}$

Islamiyah melambangkan keislaman sebagai penegasan bahwa yang dilakukan adalah dakwah tentang ajaran agama Islam. Istilah yang digunakan dalam al-Qur'an tentang dakwah: dakwah, tabligh, tanzir, tadzkirah, tabsyir, taushiyah dan juga nashihah. Ketika al-Qur'an berbicara tentang dakwah maka dituturkan yang harus di-dakwahkan adalah sabili rabbike (diartikan din al-Islam) dan atau dituturkan al-Khayr (Q.S. an-Nahl: 6).

Dakwah Islamiyah berarti memanggil dan mengajak umat manusia khususnya umat Islam untuk beriman dan menjalankan ajaran Islam sebagaimana yang diajarkan Rasulullah saw untuk kebahagiaan dunia dan akhirat.

\section{2). Dasar, Tujuan dan Komponen Dakwah Islamiyah}

Sebagai agama yang memberikan rahmat bagi semua manusia, dakwah dalam ajaran Islam didasarkan pada Al-Qur'an dan al-hadis, sebagaimana pada Q.S Ali-Imran: 104, tentang seruan untuk menyeru pada amar ma'ruf nahi munkar. Al-Qur'an adalah kitab dakwah yang mengatur dan menjelaskan segala sesuatu yang berkenaan dengan dakwah, baik dari aspek substansi maupun metodologi, sehingga al-Qur'an merupakan rujukan utama dalam setiap kegiatan dakwah.

Salah satu tujuan utama dakwah membentangkan salah satu jalan Allah di atas bumi agar dilalui manusia. ${ }^{12}$ Dakwah Islamiyah yang dilaksanakan bertujuan untuk menjadikan orang beragama bagi yang belum beragama dan bagi yang beragama Islam untuk taat pada ajaran agama Islam, sebagaimana yang telah disampaikan oleh Rasulullah saw.

Dakwah, pada dasarnya adalah ajaran agama yang ditujukan sebagai rahmat untuk semua, yang membawa nilai-nilai positip, seperti rasa aman, tentram, sejuk (al-aman), selanjutnya, dakwah dapat dirumuskan sebagai: apa yang diserukan atau disampaikan oleh siapa, kepada siapa, dengan cara bagaimana, melalui media apa, dan untuk apa ${ }^{13}$ rumusan dakwah ini merupkan komponen dalam berdakwah.

\footnotetext{
${ }^{11}$ Umar Hasyim, Mencari Ulama Pewaris Nabi, (Surabaya: PT. Bina Ilmu, 1983), h. 28.

${ }^{12}$ Asep Muhiddin dan Agus Ahmad Safei, Metode ..., (Bandung: Pustaka Setia, 2002). h. 177.

${ }^{13}$ Asep Muhyiddin, Dakwah..., (Bandung: CV. Pustaka Setia, 2002), h. 23.
} 


\section{b. Hakikat Pendidikan Islam}

\section{1). Pengertian Pendidikan Islam}

Istilah yang digunakan untuk pendidikan Islam yaitu: tarbiyah, ta'lim, riyadhah dan ta'dib. Menurut Soebahan istilah pendidikan yang relevan dengan rekaan konsep bahasa arab adalah tarbiyah, sehingga Tarbiyah Islamiyah, bukan ta'lim Islamiyah maupun Ta'dib Islamiyah. ${ }^{14}$

Pendidikan Islam menurut Ramayulis, adalah suatu proses edukatif yang mengarah kepada pembentukan akhlak atau kepribadian. ${ }^{15}$ Menurut Uhbiyati hakikat pendidikan Islam adalah proses pembimbingan dan mengarahkan pertumbuhan dan perkembangan anak didik agar menjadi dewasa sesuai dengan tujuan Pendidikan Islam.

Pendidikan Islam suatu proses, dimana dilaksanakannya memerlukan waktu untuk merubah seseorang menjadi manusia yang sesuai dengan tuntunan Islam. ${ }^{16}$

\section{2). Tujuan Pendidikan Islam}

Tujuan Pendidikan Islam memiliki 4 (empat) aspek yaitu: ${ }^{17}$

1) Tujuan jasmaniyah (abdaf al-Jinsiniyah)

2) Tujuan rohaniyah (abdaf al-rubiyyah)

3) Tujuan akal (abdaf al-aqliyah)

4) Tujuan sosial (ahdaf al-ijtima'iyyah)

Tujuan Pendidikan Islam menurut Abrasy dalam Uhbiyati secara umum adalah:

1) Untuk mengadakan pembentukan akhlak yang mulia.

2) Persiapan untuk kehidupan dunia dan kehidupan akhirat

3) Persiapan untuk mencari rezeki dan pemeliharaan segi manfaat.

4) Menumbuhkan semangat ilmiah pada pelajar

5) Menyiapkan pelajar dari segala profesional, teknikal dan pertukangan. ${ }^{18}$

Tujuan umum ini adalah untuk perubahan-perubahan yang dikehendaki yang di-usahkan oleh pendidikan untuk mencapainya, sedangkan untuk tujuan

\footnotetext{
${ }^{14}$ Soebahan, Ilmu Pendidikan Islam, (Jakarta : Rineka Cipta, 2002), h. 12

${ }^{15}$ Ramayulis, Imu Pendidikan Islam, (Jakarta: Kalam Mulia, 2004), h. 3.

${ }^{16}$ Uhbiyati, Ilmu Pendidikan Islam, (Jakarta: Rineka Cipta, 1999), h.18.

${ }^{17}$ Ramayulis, Ilmu...h, 75.

${ }^{18}$ Uhbiyati, Ilmu..., ..h. 5.
} 
khusus adalah gabungan pengetahuan, keterampilan, pola-pola tingkah laku, sikap, niai-nilai dan kebiasaan yang sesuai dengan keislaman, namun demikian tujuan pendidikan Islam merupakan gambaran nilai-nilai Islami atau terwujudnya nilai-nilai Islami pada pribadi manusia-didik sebagai hamba Allah yang diciptakan untuk mengabdi kepada-Nya dan sebagai khalifatul ardh.

\section{c. Hakikat Ulama dalam Dakwah dan Pendidikan}

\section{1). Pengertian Ulama}

Kata 'Ulama' merupakan pungutan dari bahasa asing (arab). Menurut Djalinius Syah ulama berarti orang yang ahli dalam hal atau dalam pengetahuan agama Islam. Ulama berasal dari bahasa Arab, ulama jamak dari 'alim yang berarti orang yang berilmu, ${ }^{19}$ sedangkan dalam Bahasa Indonesia digunakan dalam bentuk tunggal bukan jamak. ${ }^{20}$ Identitas kata "ulama " yang masih bersifat umum ditujukan kepada pemuka agama Islam, jarang didengar orang memanggil seseorang dengan "pak ulama", secara khusus sebutan lain sesuai budaya setempat, menyebut ulama dengan "kiyai, tuan guru, syekh, datu, qadhi, mufti, mu'alim dan ustad ${ }^{21}$ Secara khusus menurut Poerwadarminta ${ }^{22}$ menegaskan bahwa ulama adalah orang yang ahli dalam pengetahuan agama Islam, atau orang pandai-pandai dalam hal agama Islam.

Predikat orang yang disebut sebagai ulama adalah sosok seseorang yang menunjukkan adanya kepemilikan ilmu pengetahuan terutama ilmu agama Islam, ber-pengalaman yang luas serta mengetahui berbagai hal tentang ajaran Islam. Ulama yang diberikan pada seseorang menunjukkan secara pribadi walaupun maksud dari asal katanya menunjukkan jamak atau beberapa orang, ulama yang disebut cendekiawan tentunya cendekiawan muslim.

Secara istilah, menurut Harun Ulama adalah orang yang mendalami ilmu pengetahuan, baik ilmu pengetahuan yang bersumber dari Allah swt yang kemudian disebut ulumuddin, maupun ilmu pengetahuan yang bersumber dari hasil penggunaan potensi akal dan indera manusia dalam memahami ayat-ayat

${ }^{19}$ Djalinius Syah (et.al), Kamus Pelajar..., (Jakarta: Rineka Cipta, 1993), h. 260.

${ }^{20}$ Makkie, dkk. Ulama Kalimantan dari Masa Kemasa, edisi pertama, (Kalimantan Selatan: Abadi Ofset, 2010), h. xxi. Pengantar dari Mujiburrahman dalam 'Selayang Pandang Ulama Banjar dari Masa ke Masa".

${ }^{21}$ Makkie, dkk, Ulama...h. xxii.

${ }^{22}$ W.J.S. Poerwadarminta. Kamus Umum Bahasa Indonesia. (Jakarta: PN. Balai Pustaka. 2003), h. 120. 
kauniyah yang kemudian disebut ulumul insaniyah atau al-ulum (sains) ${ }^{23}$. Mujieb menyatakan ulama ialah orang yang berilmu, yang mengamalkan ilmunya dan dapat mempergunakan ilmunya secara tepat sesuai yang dikehendaki Allah swt. $^{24}$

Pengertian ulama baik secara bahasa maupun istilah pada prinsipnya adalah orang-orang yang memiliki ilmu pengetahuan terutama ilmu agama Islam, konsekuen dan komitmen dengan keilmuannya dan mengamalkannya secara profesional.

Ulama tersebut memiliki karakteristik tertentu sehingga dapat terwujud umat Islam yang dapat menjalankan ajaran Islam dengan baik.

\section{2). Karakteristik Ulama}

Predikat ulama tentunya orang yang mempunyai pengetahuan, wawasan dan keterampilan agama yang tidak diragukan lagi, namun demikian agar integrasi kepribadian mereka teruji sehingga patut diteladani sifat, sikap dan perilaku dengan akhlak terpuji. Mujieb menyebutkan 8 (delapan) syarat sekaligus karakteristik ulama, yaitu:

1. Tidak menggunakan ilmu pengetahuan untuk kepentingan/mencari untung.

2. Konsekuen terhadap perkataan.

3. Mengutamakan ilmu akherat.

4. Sederhana dan zuhud.

5. Menjauhkan diri dari penguasa zalim.

6. Tidak tergesa-gesa memberi fatwa.

7. Meningkatkan ilmu batin dan memperhatikan gerak-gerik hati.

8. Memperkuat keyakinannya. ${ }^{25}$

Menurut Zaidan ada 6 (enam) hal yang mesti dimiliki oleh ulama, yaitu iman yang kuat, berlaku sabar, kasih sayang, merendahkan diri, bergaul dan beruzlah. $^{26}$

${ }^{23}$ Harun Nasution (eds.) Ensiklopedi Islam 3, Jakarta: Departemen Agama, Ditjen Bimbaga Islam. 1992/1993), h. 1250.

${ }^{24}$ Mujieb AS Abdullah. Ciri-ciri Ulama Dunia Akherat. (Surabaya: CV. Mahkota. 1989), h. 3 .

${ }^{25}$ Mujieb AS Abdullah. Ciri-ciri Ulama..., h. 17. 
Menurut Mastuhu, karakteristik ulama yang mendasar: memiliki kepribadian yang khas dan menawan, jujur, sederhana, amanah, heroik, berjiwa pemimpin, dan penuh rasa tanggungjawab, diwujudkan dalam gerak kehidupan bermasyarakat melalui kerja keras untuk mencapai ridha Allah swt. ${ }^{27}$

Menurut Abul A’la al-Maududi seorang mujaddid yang terkenal abad ke 20 mengatakan bahwa kriteria ulama sebagai berikut:

1. Hatinya bersih.

2. Berpandangan tajam.

3. Berpikiran lurus, tidak bengkok.

4. Berkemauan luar biasa untuk mengambil jalan tengah antara berlebihlebihan dan mengabaikan serta menjaga keseimbangan antara keduanya.

5. Memiliki daya pikir yang kuat, tidak terpengaruh oleh kekuatan yang sedang berkuasa, tidak fanatik terhadap golongan yang dahulu pernah bertengger beberapa abad lamanya.

6. Tangguh didalam mengahadapi tantangan zaman yang setiap saat mengalami perubahan.

7. Cakap bila menerima suatu kepemimpinan.

8. Mampu berijtihad dan bekerja dalam lapangan pembangunan.

9. Meyakini sepenuhnya tentang ajaran Islam.

10. Pandangannya, pahamnya dan perasaannya mencerminkan sebagai seorang muslim hakiki.

11. Dapat membedakan antara Islam dan jahiliyah sampai keakar-akarnya dan masalah yang sekecil-kecilnya sekalipun.

12. Dapat menjelaskan dengan hak dan membedakannya dari gulita ajaran dusta yang lebih bercokol beberapa abad lamanya. ${ }^{28}$

Karakteristik ulama tersebut telah tergambar pada diri Nabi dan Rasul, sehingga ulama dengan segala keutamaan yang dimiliki dapatlah dikatakan sebagai pewaris para tugas para Nabi (waratsatul anbiya). Jiwa besar seorang ulama akan senantiasa menghiasi seluruh sikap, sifat dan perilaku kesehariannya.

${ }^{26}$ Abdul Karim Zaidan, Ushulud Dakwah (terj. H.M. Aswadie Synkur), (Jakarta: Media Dakwah, 1999), h. 32.

${ }^{27}$ Mastuhu, Pemberdayaan Sistem Pendidikan Islam, (Jakarta: Logos, 1999), h. 248.

${ }^{28}$ Abul A'la al-Maududi, Tajdid ad-Din wa Ibyaibi .(terj. Ahmadie Thaha dan Saipul Islam Farenduani), 1984, h. 50. 


\section{3). Peran Ulama}

Peran $^{29}$ seperangkat tingkat yang diharapkan dimiliki oleh orang yang ber-kedudukan di masyarakat. Peran seseorang di masyarakat dinampakkan dari tingkah laku yang ditampilkannya dalam kesehariannya pada pergaulan seharihari atau dengan kata lain amal nyata yang diperlihatkan bukan hanya sebatas kata-kata semata.

Keberadaan ulama di lingkungan masyarakat akan mampu mempertahankan statusnya sebagai pewaris simbol-simbol Islam, sehingga kepentingan ulama pasti ber-kaitan dengan masa depan Islam, bahkan ada yang menyebutkan ulama-pendidik tiga zaman.

Menurut Umar Hasyim peranan dan fungsi ulama minimal ada 6 (enam) yaitu:1) Penganjur agama Islam, 2) Pemimpin rohani, 3) Pengemban amanah Allah, 4) Pembina umat, 5) Penuntun umat, dan 6) Penegak kebenaran. ${ }^{30}$

Keutamaan ulama telah disebutkan dalam ayat al-Qur'an yang berbunyi:

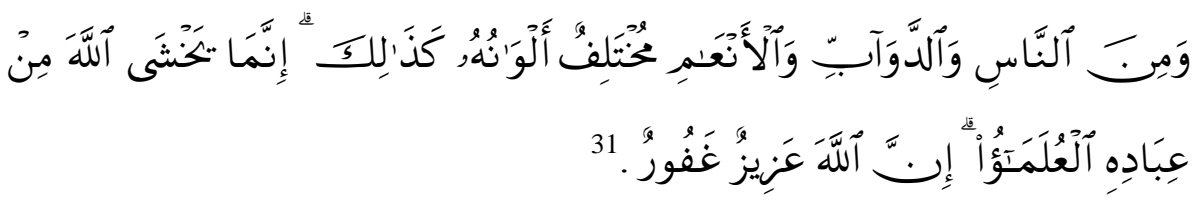

Dan diantara manusia, binatang-binatang melata dan binatang-binatang ternak bermacam-macam warnanya seperti itu (pula), sesunggubnya yang takut kepada Allab diantara hamba-hamba-Nya, hanyalah ulama, sesunggubnya Allah Maba Perkasa lagi Maha Pengampun.

Kata ulama bentuk jamak dari kata 'alim yang berarti mengetahui secara jelas. Ulama pada ayat tersebut "yang berpengetahuan agama", ilmuwan yang mengetahui rahasia-rahasia penciptaan sebagai kelompok yang paling takut kepada Allah. ${ }^{32}$

Sejarah memberikan kesaksian akan kenyataan bahwa selama ulama menunaikan kewajiban dengan segala konsekuensinya secara benar, masyarakat kita (umat Islam) menjadi umat yang terpandang. Manakala hal ini

${ }^{29}$ Windy Novia, Kamus Lengkap Bahasa Indonesia, (Surabaya: Kashiko, t.th), h. 343.

${ }^{30}$ Umar Hasyim, Mencari Ulama Pewaris para Nabi, (Surabaya: PT. Bina Ilmu, 1983), h. 135.

${ }^{31}$ Q.S. Al-Fathir ayat 28.

${ }^{32}$ M. Quraish Shihab. Tafsir al-Mishbah volume 3, (Jakarta: Lentera Hati, 2005), h. 465. 
direalisasikan secara konsekuen (istiqamah), maka pada gilirannya nanti akan mampu melahirkan kebudayaan dan peradaban yang memiliki daya saing sehingga sanggup memimpin dunia.

Keberadaan ulama yang diumpamakan juga cahaya yang menerangi dan dapat menyelamatkan umat manusia dari perbuatan yang salah menuju perbuatan yang benar. Betapa banyak ulama yang sering juga disebut Kyai, Da’i maupun sebutan Tuan Guru yang memberikan tenaga dan pikirannya kepada perkembangan ajaran Islam di dunia maupun di akherat, semua diharapkan untuk memberikan kejayaan Islam, kebahagiaan umat Islam di dunia dan di akhirat kelak.

Keberadaan ulama ditengah masyarakat sebagai da'i maupun sebagai pendidik, memiliki majelis-majelis taklim maupun pondok pesantren, tentunya berpengaruh signifikan dan sangat menentukan terhadap kualitas keimanan kaum muslimin, sehingga umat Islam bukan hanya mayoritas (kuantitas) tapi juga berkualitas (memiliki keimanan yang kuat: perkataan sejalan dengan perbuatan).

Andil para ulama tidaklah kecil dalam menciptakan sumberdaya manusia untuk kepentingan bangsa dan negara, tanggungjawab yang paling utama adalah terhadap Allah swt kelak dikemudian hari.

\section{Biografi KH. Ibrahim}

KH. Ibrahim dilahirkan di Pantai, Kotabaru, Kalimantan Selatan pada tanggal 28 Agustus tahun 1932, dari anak H. Muhammad Nuh. Memiliki 5 (lima) orang saudara yaitu: Diang, Hasan Basri, Jaibah, Saniah dan Hj. Radiah. Wafat dan dimakamkan pada tanggal 3 September 1999 di Palangka Raya.

Sebelum berkeluarga, merantau ke Banjarmasin dan pernah menjadi pejuang / tentara (veteran) dan pada waktu itu pimpinan veteran juga menjadi guru beliau. Berjuang sebagai gerilyawan dan tinggal di Desa Tatah Pamangkih Kelayan Gang Sadar Banjarmasin. Setelah berkeluarga dengan Hj. Fatimah memiliki 3 (tiga) orang anak, yaitu:

1. Fauzi Ibrahim (H. Fauzi Ibrahim)

2. Enor (Hj. Enor), dan

3. Salamah

Setelah menjadi veteran atau bukan lagi sebagai tentara, beliau sambil belajar ilmu agama, juga menjadi tukang parkir di halaman Kantor Pos Kelayan Banjarmasin. Kegiatan belajar agama dilakukan setelah pekerjaan selesai yaitu 
sore hingga malam hari. Kemudian pada tahun 1963 merantau kembali ke Kotabaru, namun tanpa diikuti isteri beliau, hanya diikuti oleh anak tertua (Fauzi Ibrahim, pada waktu itu), sedangkan anak yang lain mengikuti isteri beliau (berpisah dengan isteri).

Kembali ke Kotabaru mulai berdakwah sambil berdagang kain dan sirap ulin, dari kota, desa bahkan dusun ke dusun, sambil berdagang juga sebagai juru dakwah. Selanjutnya, beliau menikah dan berkeluarga kembali dan memiliki 1 (satu) orang anak yang bernama Junaidi (H. Junaidi) namun tidak lama (isteri beliau wafat).

Perjalanan dakwah sambil berdagang di Kotabaru hingga ke Batu Besar, di Batu Besar membuat sebuah Pesantren yang dilaksanakan di rumah berupa pengajian, sekitar tahun 1965. Perjalanan dakwah sambil berdagang hingga sampai ke Desa Sampanahan, di Sampanahan menjadi pernah dipercaya oleh masyarakat sebagai Kepala Desa atau Pambakal dan kemudian sekitar tahun 1967 menikah dengan Hj. Masja, ${ }^{33}$ memiliki 10 orang anak, yaitu : 1. H. Ahmad Sanusi, 2. H. Abdul Sani, 3. H. Muhammad Siddiq, 4. Hj. Salasiah, 5. H. Harmain, 6. Siti Salhah, 7. Khairul Atqiya, 8. Ahmad Yasir, 9. Ani Irma, dan 10. Syehabuddin.

Perjalanan dakwah dan dagang kadang dilakukan sambil berperahu/berlayar dari kampung ke kampung, dusun ke dusun. KH. Ibrahim tidak pernah mengikuti pendidikan secara formal namun belajar mengaji dari satu guru ke guru lain, seperti : 1. Guru Ja'far, 2. Guru Zakaria, 3. Guru Muhammad Arsyad, dan 4. Guru Haji Darman.

Guru Zakaria, merupakan guru yang paling banyak diperoleh ilmu-ilmu ke-agamaan, baik fikih, nahu-syaraf, mu'amalah maupun tasawuf. Pelajaran tasawuf lebih banyak diperoleh pada guru Haji Darman. ${ }^{34}$

Sekitar tahun 1986, oleh anak beliau (Muhammad Fauzi) dan juga cucu beliau (H. Ahmad Iskandar Arsyad ${ }^{35}$ mengajak untuk hijrah ke Kota Palangka

${ }^{33}$ Berdasarkan informasi dari beberapa sumber beliau pernah memiliki isteri namun tanpa mempunyai anak sebelum dengan $\mathrm{Hj}$. Masja.

${ }^{34} \mathrm{KH}$. Ibrahim memiliki banyak guru, diantaranya juga adalah Guru Tokat, ketika berada di Pantai Hambawang, Barabai. Guru Tokat adalah seorang ulama yang disegani. Beliau juga belajar bahasa Inggris, wawancara dengan H. Ahmad Sanusi, Oktober 2011.

${ }^{35} \mathrm{H}$. Ahmad Iskandar Arsyad merupakan cucu KH. Ibrahim anak dari KH. Muhammad Arsyad ulama dari Kotabaru Kalimantan Selatan, juga sebagai penceramah dan merupakan Pegawai Pengadilan Tinggi Agama (PTA) Palangka Raya, sekarang telah pensiun. 
Raya, dan tujuan utama adalah berdagang, oleh anak beliau disiapkan toko untuk berdagang, sebagaimana wawancara berikut:

Abah, ulun minta untuk datang ke Palangka Raya, ulun siapkan toko untuk sidin badagang. ${ }^{36}$

Sekitar tahun 1985 KH. Ibrahim merantau ke Palangka Raya, Kalimantan Tengah, sebagaimana ajakan cucu tersebut, dan akan disiapkan oleh anak, toko untuk berdagang. Namun, keberadaan di Palangka Raya bukan sebagaimana tujuan awal berdagang, namun menjadi juru dakwah, hal ini diawali dengan menggantikan jadwal ceramah KH. Ahmad Iskandar Arsyad.

Perkembangan selanjutnya, dari hari ke hari, minggu dan tahun, kepadatan jadwal ceramah agama melupakan usaha beliau untuk berdagang, bahkan jamaah yang mengaji kepada beliau bukan hanya yang di undang untuk ceramah juga jamaah yang datang ke rumah untuk belajar agama. Selanjutnya mendirikan Pondok Pesantren Hidayatul Insan Fita'limiddin (alamat: Jalan Sulawesi No. 76 Palangka Raya) serta majelis-majelis Taklim yang dilaksanakan di masyarakat (dari rumah-ke rumah).

Biografi yang singkat, tentang KH. Ibrahim dengan 3 (tiga) isteri dan telah dikaruniai 14 orang anak, dan beberapa anak melanjutkan perjuangan dakwah beliau, seperti H. Ahmad Sanusi yang kini menjadi pimpinan Pondok Pesantren al-Madaniyah di Kecamatan Jaro dan pengasuh Perguruan Islam Terpadu (SD, SMP dan SMA) Hasbunallah di Kota Tanjung, Kalimantan Selatan. Khusus untuk santri Pondok Pesantren al-Madaniyah, sebagian muridnya dari wilayah Kalimantan Timur dan pulau Jawa. Begitu pula anak beliau (H. Harmain) yang sekarang menggantikan diamanahkan untuk menjadi pimpinan Pondok Pesantren Hidayatul Insan Fita'limiddin Kota Palangka Raya, sekaligus juga mengajar dan memberikan bimbingan rohani kepada masyarakat dan juga anggota Komisi Pemilihan Umum (KPU) Kota Palangka Raya periode 2008-2013, dan beberapa anak lainnya menjadi tenaga pengajar di Pondok Pesantren Hidayatul Insan Fita'limiddin tersebut.

Pendidikan yang diperoleh beliau tanpa melalui jalur formal, dari beberapa guru tersebut terutama ketika berada di Kelayan Banjarmasin, sambil menjadi juru parkir, dan ketika kembali lagi ke Kotabaru menjadi seorang Da'i, namun tetap sambil berdagang dari desa dan dusun hingga berbagai pelosok dengan menggunakan perahu/berlayar. Selanjutnya, kemampuan dakwah/sebagai Da'i yang menyampaikan ajaran agama kepada masyarakat

${ }^{36}$ Wawancara dengan H. Muhammad Fauzi, September 2011. 
dapat dikatakan merupakan merupakan potensi yang juga ada pada orangtua beliau (H. Muhammad Nuh). ${ }^{37}$ Berdasarkan hal tersebut juga anak-anak dari KH. Ibrahim sebagian menjadi seorang pendakwah: penceramah, guru agama Islam dan pengasuh Pondok Pesantren.

\section{Peranan KH. Ibrahim dalam Dakwah dan Pendidikan}

Peranan merupakan serangkaian tingkah laku yang berkaitan dengan yang dilakukan seseorang dalam situasi tertentu, serta berhubungan dengan kemajuan dan perkembangan tingkah laku. ${ }^{38}$ Seseorang yang akan diangkat adalah KH. Ibrahim (alm.) dalam dakwah dan pendidikan Islam.

Informasi tentang peran tersebut, akan diungkapkan melalui: 1) aktivitas dakwah dan pendidikan, 2) sikap dalam berdakwah dan pendidikan yang dilaksanakan, dan 3) Referensi yang telah dibuat.

\section{Aktivitas Dakwah dan Pendidikan}

Aktivitas dakwah dan pendidikan yang dilakukan oleh KH. Ibrahim, yang diawali dengan kedatangan ke Kota Palangka Raya pada tahun 1985. Perkembangan selanjutnya setelah di Kota Palangka Raya lebih pada aktivitas juru dakwah (ber-ceramah), bermula dari menggantikan jadwal ceramah KH. Ahmad Iskandar Arsyad. Semakin banyak permintaan untuk mengisi jadwal pengajian yang harus beliau laksanakan, sebagian lagi ada yang datang ke rumah.

Berdasarkan wawancara yang dilakukan bahwa : Ketika berdomisili di Jalan Sulawesi No. 76 Palangka Raya, mendirikan Yayasan Hidayatul Insan Fita'limiddin, yang mulanya hanya pengaiian biasa.

Yayasan ini yang selanjutnya menjadi sebuah pesantren walaupun masih berupa pengajian di rumah saja, sebagai upaya untuk merubah keadaan masyarakat sekitar (Jalan Sulawesi pada waktu itu), masyarakat sangat memerlukan bimbingan keagamaan Islam, apalagi Palangka Raya pada waktu itu masih minim sarana peribadatan dan lembaga pendidikan yang berciri khas

${ }^{37}$ Berdasarkan informasi dari M. Siddik salah satu anak beliau: menurut pa Iskandar, sidin berdakwah, sambil berdagang, sangat apik dengan hukum, contoh menjual celana pendek kada mau, laki-laki memakai sepeda perempuan kada boleh karena menyerupai perempuan. Sidin berdagang tapi mengajar agama di rumah, Desember 2011.

${ }^{38}$ Muh. Uzer Usman, Menjadi Guru Profesional, (Bandung: PT. Remaja Rosdakarya, 1992), h. 4. 
Islam, demikian juga jumlah majelis taklim yang masih terbatas padahal masyarakat sangat memerlukan bimbingan keagamaan tersebut.

Awal mula yayasan hanya merupakan tempat berkumpul untuk mendengarkan ceramah agama dari KH. Ibrahim yang dibantu oleh anak beliau H. Ahmad Sanusi, selanjutnya menjadi sebuah pesantren walaupun sangat sederhana dengan awal swadaya keuangan mandiri, Pesantren yang bernama Hidayatul Insan Fita'limiddin diambil dari buku tauhid tulisan tangan beliau sendiri, sebagaimana wawancara berikut:

Nama Pesantren dari nama buku tauhid: Tauhid Hidayatul Insan Fita'limiddin. Legalitas formal Pondok Pesantren ini terdaftar pada Akte Notaris No. 16 tahun 1991 tanggal 10 April 1991. Keberadaan Pondok Pesantren ini pada awalnya menghadapi tantangan bahkan gunjingan, fitnah, terutama oleh masyarakat non Islam, karena di lingkungan pondok tersebut, terdapat umat non muslim yaitu Kristen (terkadang oleh orang Kristen tersebut, saat azan dilempari mereka dengan batu dan telur busuk, pernah juga ada yang mengatas namakan pesantren untuk minta sumbangan, padahal tidak benar,. Namun demikan sikap umat non muslim tersebut tidak dilayani oleh KH. Ibrahim beserta jamaah pondok, hal ini jugalah kemudian disikapi oleh kepindahan umat non muslim tersebut untuk pindah berdomisili ketempat lain.

Beberapa wawancara yang dilakukan tentang aktivitas KH. Ibrahim selain pendirian Pondok Pesantren tersebu bahwa: majelis maupun pengajian yang dilakukan KH. Ibrahim, ada yang dilakukan di rumah sehingga murid/jamaah yang menemui beliau, dan ada yang didatangi baik rumah-kerumah dengan hari dan jam yang sudah disepakati. Pelajaran yang diberikan : Fikih, nahu-sharaf, baca al-Qur'an dan tasawuf, namun yang lebih banyak adalah pelajaran tauhid (sifat dua puluh tersebut).

Aktivitas dakwah dan pendidikan yang dijalankan hampir setiap hari, tak mengenal lelah, bahkan dalam keadaan sakitpun tetap datang menemui jamaah yang sudah terjadwal .

Ketekunan KH. Ibrahim menyampaikan dakwah dan pendidikan kepada masyarakat terkadang melupakan kesehatan sendiri, walaupun sedang sakit selama bisa dilaksanakan, maka pengajian tetap dilaksanakan.

Aktivitas dalam dakwah dan pendidikan yang dilakukan KH. Ibrahim; sebagai bentuk dakwah maupun bentuk pendidikan telah memenuhi kriteria komponen dakwah maupun pendidikan, sebagai komponen dakwah/pendidikan seperti: 
1. Pendidik: adalah KH. Ibrahim, walaupun terkadang anak beliau juga membantu dalam pelaksanaan pengajaran, terutama pada pelajaran baca tulis al-Qur'an.

2. Peserta didik: usia remaja baik laki-laki maupun perempuan, kalangan ibu rumah tangga dan bapak-bapak.

3. Obyek: memberikan pengajian rutin maupun terjadwal kepada masyarakat, baik dalam skala besar (seperti Peringatan Hari-hari Besar Islam / PHBI) maupun kelompok yang dilaksanakan secara rutin dan terjadwal.

4. Materi : materi yang disampaikan berupa fikih, nahu dan syaraf, tauhid (materi ini yang lebih banyak dan rutin di sampaikan kepada jama'ah baik dari rumah-kerumah maupun yang belajar langsung datang kerumah)

5. Metode : hapalan, ceramah, penugasan, dikte dan latihan.

6. Media : untuk pelajaran Tauhid menggunakan panduan tauhid yang ditulis dengan tangan KH. Ibrahim yang berjudul : Hidayatul Insan Fita'limiddin Tauhid.

7. Waktu : pelaksanaan pembelajaran pagi, siang, sore, dan malam hari, dengan jadwal yang telah ditentukan dan ada yang insidentil.

Selain hal tersebut, Strategi dakwah yang dilakukan beliau: Mengcopy materi untuk dimiliki jama'ah, sehingga pembelajan tetap selalu diingat dan dimiliki.

Keberadaan Pondok Pesantren yang dirintis oleh KH. Ibrahim hingga saat ini mengalami perkembangan yang baik, bahkan bukan hanya pengajian semata, telah diselenggarakan pendidikan dari usia dini: Taman Kanak-kanak (TK), Taman Asuh Anak Muslim (TAAM), TK Al-Qur'an (TKA), Madrasah Ibtidaiyyah (MI), Madrasah Tsanawiyah (MTs), Madrasah Aliyah (MA) dan pondok asrama santri yang menginap. Berdiri juga Masjid Hasbunallah yang dipergunakan untuk pelaksanaan ibadah shalat Jum'at bagi masyarakat Islam sekitarnya. Keberadaan Pondok Pesantren hingga saat ini mayoritas di kelola oleh anak-anak KH. Ibrahim, hal ini juga pernah diungkapkan kepada anakanak beliau untuk membantu pelaksanaan dakwah dan pendidikan Islam, pada H. Muhammad Siddiq, pada waktu itu bekerja / dinas di Pangkalan Bun, dan 
diminta pindah untuk kumpul dengan beliau; pesantren teruskan, pernah juga menggantikan untuk mengajarkan al-Qur'an pada jama'ah beliau.

\section{Sikap dalam Berdakwah dan Pendidikan}

Sikap dalam berdakwah dan pendidikan yang dilaksanakan KH. Ibrahim bahwa: istiqomah dalam berjuang menyampaikan dakwah Islamiyah dan pendidikan Islam kepada masyarakat. Bahkan kondisi ekonomi yang dialami dan dijalani tidak menyurutkan gerak langkah dakwah pendidikan yang dijalankan, demikian juga untuk kehidupan anak-anaknya, karena beliau yakin Allah akan menolong sebagaimana jaminan Allah swt pada surah at-Thalaq ayat 2 .

Istiqomah yang ditampilkan oleh KH. Ibrahim juga nampak pada cara meng-ajarkan pelajaran tauhid, baik di lingkungan pesantren maupun di rumahrumah masyarakat, tanpa membeda-bedakan; yaitu dibacakan diikuti oleh santri/jamaah lalu nanti untuk dihapalkan. Kondisi apapun tetap menyampaikan dakwah dan berjuang untuk pendidikan umat Islam, padahal keadaan ekonomi yang tak seberapa kemudian harus memberi nafkah pada anak-anak beliau, tetap berdakwah, Istiqamah ${ }^{39}$ tidak akan tegak tanpa kekuatan insaniyah yang ada di dalam diri manusia, tetapi lebih dari itu, istiqamah tidak akan tumbuh kalau tidak dilandasi oleh iman.

Sikap-sikap yang ditampilkan beliau dalam mengajarkan/berdakwah kepada umat Islam, tak kenal lelah, bahkan suara pecah tak mengendorkan semangat juang yang dijalankan dalam berdakwah. Masyarakat dapat menerima pembelajaran yang dilakukan terutama pelajaran fikih, demikian juga pelajaran tauhid; sifat dua puluh yang mudah dipahami oleh jamaah. KH. Ibrahim adalah pengajar yang tak pernah ada masalah dengan masyarakat.

Kepada anak dan menantu terkadang memberikan pelajaran-pelajaran yang dapat diamalkan langsung baik untuk diri sendiri maupun untuk diamalkan kepada masyarakat, namun ada juga pengetahuan yang tidak berkenan untuk disampaikan, karena sunnatullah.

Sikap-sikap yang ditampilkan oleh KH. Ibrahim membuat perkembangan pesantren dari hari ke hari mengalami kemajuan, kendala yang dihadapi, pernah terjadi kebakaran, namun kemudian berdiri lagi pesantren tersebut, apabila musim hujan mengalami kebanjiran, semua disikapi dengan sabar, tabah, tawakkal, ikhlas serta istiqamah.

${ }^{39}$ Yunasril Ali, Pilar-pilar Tasawnf, Jakarta: Kalam Mulia, h. 78. 
Perhatian terhadap masyarakat dalam bimbingan keagamaan, berusaha untuk memberikan kemudahan dalam mempelajari agama seperti pelajaran tauhid, yakni dalam tulisan beliau:

$$
\begin{aligned}
& \text { ادا فون كمودئن در فدا ايت ستله ساي با يق مغلمي كسوكاران- كسوكاران دالم مغرجكن فلا } \\
& \text { جران اكام دي بحليس تعليم تراوتما سكل دالم فلاجران علمو تو حيد - مكا ساي سوسونله ر } \\
& \text { سا له يغ كحيل اين دان ساي نمايء هدا ية الانسان فن تعليم التوحيد = ارتيث فتوبتوق منو } \\
& \text { سيا دابم ممفلا جري علمو تو حيد - مكاساي سمولا ايله اكن مغكمبركن حل - حل يغ } \\
& \text { سواجرث دلم اسي رساله اين سو فاي موده د فلا جري اوله اورغ - اورغ يغ برو بلا جر علمو } \\
& \text { تو حيد } 40 .
\end{aligned}
$$

(Adapun kemudian pada itu setelah saya banyak mengalami kesukaran dalam mengajarkan pelajaran agama di majlis ta'lim terutama sekali di dalam pelajaran ilmu taubid - maka saya susunlah Risalah yang kecil ini dan saya namai Hidayatul Insan fi Ta'lim Taubid = artinya petunjuk manusia mempelajari ilmu taubid - maksud saya semula ialah akan menggambarkan hal-bal yang sewajarnya dalam isi Risalah ini supaya mudah dipelajari oleh orang-orang yang baru belajar ilmu taubid).

Apa yang dikatakan KH. Ibrahim pada tulisan tangan tersebut, tergambar bahwa beliau berupaya memberikan kemudahan kepada orang yang akan mempelajari ilmu tauhid, walaupun ditulis dalam bahasa Arab Melayu (ditulis dengan teks Arab namun berbahasa Indonesia).

Sikap yang ditampilkan telah nampak sebagai seorang ulama, sebagaimana kriteria yang dikemukakan oleh Abul A'la al'Maududi: Hatinya bersih, berpikiran lurus tidak bengkok, tangguh, meyakin sepenuhnya tentang ajaran Islam $^{41}$. Sikap lain : jujur, sederhana, amanah, penuh tanggung jawab ${ }^{42}$. Sikap yang ada pada KH. Ibrahim (alm.) dapat dikatakan sebagai ulama dengan karakteristik yang ditampilkan tersebut, sehingga sebagai pewaris al-anbiya telah nampak pada diri beliau.

${ }^{40}$ H. Ibrahim Ibnu H. Muhammad Nuh, Risalah Hidayatul Insan Fita'limiddin Taubid, h. $1-2$.

\footnotetext{
${ }^{41}$ Abul A'la al-Maududi ..., h. 50.

${ }^{42}$ Mastuhu ..., h. 248.
} 


\section{Referensi yang dibuat.}

Mengajarkan pengajian rutin baik tauhid, al-Qur'an maupun fikih, dilakukan dengan buku panduan, yang masih adalah pelajaan tauhid yang ditulis dengan bahasa Arab melayu tulisan tangan beliau sendiri. Sebagai contoh:

$$
\begin{aligned}
& \text { فر تما و جو د } \\
& \text { ارتيث اد الله تعلى لا ونث عدم ارتيث تيا دا مكا وا جب الله تعلى ادا. مستحيل } \\
& \text { الله تعلى تيدا. ادا فون تند وا جب الله تعلى ادا د ا ليل عقل بهار عا لم. ادا فون } \\
& \text { داليل نقل يل يت فرمن الله تعلى د د لم القران. الله الذي خلق السموات والارض وما } \\
& \text { بينهما = ارتيث برمولا الله تعلى تله منجد يكن اي اكن ثوجه لا فيس لا عيت دان } \\
& \text { بومي دان براع انثر كدواث. }
\end{aligned}
$$

\section{Pertama Wujud}

Artinya Ada Allab ta'ala lawannya 'adam artinya tiada, maka wajib Allah ta'ala ada - mustabil Allab ta'ala tiada, adapun tanda wajib Allab ta'ala ada dalil 'aqal baharu 'alam - adapun dalil naqal yaitu firman Allab ta'ala didalam alQur'an:

$$
\text { الله الذي خلق السموات والارض وما بينهما }
$$

Artinya barmula Allah ta'ala talah manjadikan ia akan tujuh lapis langit dan bumi dan barang antara kaduanya.

Buku tauhid tersebut juga dipergunakan ditingkat Madrasah Islamiyah (MI) yang ada di lingkungan Pondok Pesantren Hidayatul Insan Fita'limiddin. Selanjutnya diterjemahkan oleh Pesantren al-Madaniyah (Pondok Pesantren di Kecamatan Jaro, yang didirikan oleh H. Ahmad Sanusi), dengan dilengkapi keterangan syarah, buku terjemahan tersebut bahkan digunakan untuk pengajian tauhid hingga ke luar negeri (Hongkong).

Peranan KH. Ibrahim baik dalam aktivitas yang dilakukan untuk umat Islam, sikap yang ditampilkan sebagai juru dakwah juga referensi yang dibuat untuk di-pergunakan kepada jamaah, merupakan perjuangan yang sangat luar biasa, bermula dari seorang pedagang sambil belajar, kemudian berdagang

\footnotetext{
${ }^{43}$ KH. Ibrahim Ibnu H. Muhammad Nuh, Risalah Hidayatul Insan Fita'limiddin Taubid, h. 5 .
} 
sambil mengajar dan belajar, hingga di akhir hayat beliau, wajarlah kiranya disebut sebagai ulama yang istiqamah dalam sikap dan perbuatan, seirama kata dan langkah, bahkan cara-cara dakwah dan pendidikan yang dijalankan seperti sabar, tidak menyingung dan sebagainya.

Sebagai pendakwah, KH. Ibrahim berupaya mengajak dan menyeru kepada umat Islam untuk menjalankan ajaran agama Islam dengan sebaikbaiknya sesuai dengan tuntunan Islam (ulama), dan sebagai pendidik, telah memberikan didikan tentang pelajaran-pelajaran keIslaman hingga materi tauhid, dengan buku Hidayatul Insan Fita'lim Tauhid juga mendirikan sebuah Pesantren, yang pada awal dibangun hanya berupa tempat kumpul untuk belajar agama kepada beliau, hingga perkembangan selanjutnya adalah pendidikan secara informal (seperti TK Al-Qur'an) dan pendidikan formal dengan adanya madrasah (sebagai tempat untuk mempelajari/menuntut ilmu).

Berbagai cobaan dan ujian dalam gerak langkah dakwah dan pendidikan yang dilakukan beliau, namun semua dijalani dengan kesabaran, keikhlasan bahkan selalu istiqomah dalam menyampaikan ajaran agama Islam, agama yang dibawa oleh Rasulullah saw, sebagai agama yang diridhai oleh Allah swt.

Sikap dakwah maupun pendidikan yang dilakukan beliau sejalan dengan firman Allah swt:

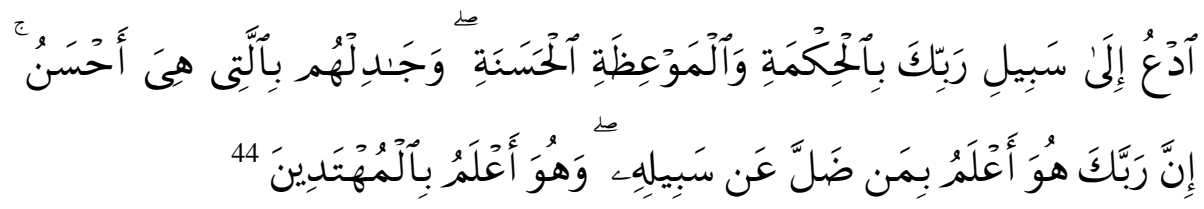

Serulah (manusia) kepada jalan Tubanmu dengan bikmah dan pelajaran yang baik dan bantablab mereka dengan cara yang baik, Sesunggubnya Tubanmu, Dialah yang lebih Mengetahui tentang siapa yang tersesat di jalan-Nya dan Dialah yang mengetahui orang-orang yang mendapat petunjuk.

Isyarat dakwah ${ }^{45}$ pada ayat tersebut, bahwa hakikat dakwah dapat dirumuskan sebagai kewajiban mengajak manusia ke jalan Tuhan dengan cara bijak, tegas dan benar (bikmah), pelajaran yang baik (manz̧ilah hasanah) dan bantahan yang lebih baik (mujadalah hasanah), adapun respon manusia terhadap ajakan ke jalan Tuhan tadi dapat positif atau sebaliknya negatif.

\footnotetext{
${ }^{44}$ Q.S. An-Nahl :125

${ }^{45}$ Asep Muhibbin, Dakwah dalam ..., h. 41.
} 
Cara-cara dakwah KH. Ibrahim, al-hikmah, al-mau'idzah dan al-jidal alabsan, merupakan prinsip dakwah Rasulullah saw terutama kepada umat Islam. Pendekatan kegiatan dakwah dan pendidikan yang telah dijalankan dilakukan dengan perkataan, perbuatan, bahkan dilengkapi dengan buku tulisan yang ditulis sendiri oleh $\mathrm{KH}$. Ibrahim tersebut.

\section{Penutup}

Biografi KH. Ibrahim, lahir di Pantai, anak dari Muhammad Nuh bin Abdul Qodir, memiliki 14 orang anak, pendidikan yang diperoleh tidak secara formal hanya mengaji duduk saja, dengan beberapa guru.

Perannya dalam bidang dakwah dan pendidikan, dapat dilihat pada: a ). Aktivitas dakwah dan pendidikan: berawal dengan berdagang dan belajar hingga hanya mengajar dan belajar saja, melalui pengajian baik di lingkungan masyarakat maupun di rumah dan Pesantren Hidayatul Insan Fita'limiddin. Potensi dakwah dan pendidikan berasal dari garis keturunan orangtuanya dan potensi ini juga diwarisi oleh anak-anaknya. Aktivitas tersebut telah tercakup komponen dakwah dan pendidikan., b) Sikap dalam beraktivitas dakwah dan pendidikan: ikhlas, sabar, istiqamah, tidak pilih kasih dan selalu berdo'a kepada Allah swt. Sikap ini merupakan karakteristik seorang ulama.c) Referensi: buku yang dipergunakan dalam pengajaran yang masih ada bahkan di-pergunakan pada pengajian tauhid, yaitu Kitab Hidayatul Insan Fita'limiddin Taubid.

\section{Daftar Pustaka}

Abdullah, Mujieb AS, Ciri-ciri Ulama Dunia Akherat, Surabaya, CV. Mahkota, 1989.

al-Maududi, Abul A'la, Tajdid ad-Din wa Ibyaibi .(terj. Ahmadie Thaha dan Saipul Islam Farenduani). 1984.

Anwar, Khairil, dkk. Kedatangan Islam di Bumi Tambun Bungai. Banjarmasin, STAIN Palangka Raya bekerjasama dengan MUI Kalteng, 2005.

Hasyim, Umar, Mencari Ulama Pewaris para Nabi, Surabaya, PT. Bina Ilmu, 1983. 
Jorjani, Skripsi : Komponen Dakwah Islamiyah Majelis Taklim Pondok Pesantren Hidayatul Insan di Kecamatan Pahandut Kota Palangka Raya, Palangka Raya; STAIN Palangka Raya, 2005.

Kaelan, Metode Penelitian Kualitatif dalam Filsafat, Paradigma bagi Pengembangan Penelitian Interdisipliner bidang Filsafat, Budaya, Sosial, Semiotika, Sastra, Hukum dan Seni. Yogyakarta, Paradigma, 2005.

Kasimi, Ahmad, Skripsi : Pengaruh Aktivitas Pengajian Tasawuf terhadap Tingkah Laku Mahasiswa STAIN Palangka Raya Jurusan Tarbiyah (studi pada Pondok Pesantren Hidayatul Insan Fita'limiddin Palangka Raya, Palangka Raya, STAIN Palangka Raya, 1998.

Makkie, dkk., Ulama Kalimantan Selatan Dari Masa ke Masa, Edisi Pertama, Banjarmasin, Abadi Offset, 2010.

Mastuhu, Pemberdayaan Sistem Pendidikan Islam, Jakarta, Logos, 1999.

Muhyiddin, Asep, Dakwah dalam Persepektif al-Qur'an, Studi Kritis atas Visi, Misi dan Wawasan, Bandung, Pustaka Setia, 2002.

Muhyiddin, Asep, dan Agus Ahmad Safei, Metode Pengembangan Dakwah, Bandung, Pustaka Setia, 2002.

Nasution, Harun (eds.), Ensiklopedi Islam 3, Jakarta, Departemen Agama, Ditjen Bimbaga Islam, 1992/1993.

Novia, Windy, Kamus Lengkap Bahasa Indonesia, Surabaya, Kashiko, t.th.

Nuh, Ibrahim Ibnu Muhammad, Risalah Hidayatul Insan Fita'limiddin Taubid, Palangka Raya, t.tt, t.th.

Poerwadarminta, W.J.S., Kamus Umum Bahasa Indonesia, Jakarta, PN. Balai Pustaka, 2003.

Rahman, Fadli, Ma'rifat, Musyabadah, Mukasyafah dan Mababbah, Paradigma Baru Neo Sufisme di Kalimantan Tengah, Malang, In-Trans, 2007.

Ramayulis, Ilmu Pendidikan Islam, Jakarta, Kalam Mulia, 2004.

Shihab, M. Quraish, Tafsir al-Mishbah (volume 3), Jakarta, Lentera Hati, 2005.

Soebahan, Ilmu Pendidikan Islam, Jakarta, Rineka Cipta, 2002.

Syah, Djalinius (et.al), Kamus Pelajar Kata Serapan Bahasa Indonesia, Jakarta, Rineka Cipta, 1993. 
Syukur, Asywadie, Pemikiran Syekh Muhammad Arsyad al-Banjari, dalam bidang Taubid dan Tasawnf. Banjarmasin, Comdes. 2009.

Uhbiyati, Ilmu Pendidikan Islam, Jakarta, Rineka Cipta, 1999.

Usman, Muh. Uzer, Menjadi Guru Profesional, Bandung, PT. Remaja Rosdakarya, 1992.

Zaidan, Abdul Karim, Usbulud Dakwah (terj. H.M. Asywadie Syukur), Jakarta, Media Dakwah, 1999. 